\title{
ASSESSing Forest CANOPY STRUCTURE IN Grand Teton National Park
}

\author{
CHRIS L. LAUVER $\uparrow$ KANSAS BIOLOGICAL SURVEY \\ UNIVERSITY OF KANSAS $\downarrow$ LAWRENCE
}

\section{Clayton F. BLODGETT $\downarrow$ KANSAS APPLIED REMOTE SENSING (KARS) PROGRAM DEPARTMENT OF GEOGRAPHY $\uparrow$ UNIVERSITY OF KANSAS \\ LAWRENCE}

\section{INTRODUCTION}

The field campaign of 1997 built upon sampling efforts which began in 1994, and were supplemented in 1995 and 1996. To date a total of sixty sites have been sampled. This field sampling effort supports a modeling effort aimed at interpolating forest canopy structure information to areas within the park that will not be sampled. This effort will result in exhaustive measures of basal area, biomass, and leaf area index for lodgepole pine forested areas within Grand Teton National Park (GTNP).

\section{OBJECTIVES}

The short term (summer 1997) objective of this research project was to increase the number of field sample sites to aid in better characterizing the lodgepole pine forests of GTNP. This sampling effort supports the global objective of the project which is to develop models of forest canopy structure (basal area, biomass, leaf area index) using standard statistical and geostatistical modeling of field survey data with Landsat Multi-Spectral Scanner (MSS) satellite imagery. Five different methods will be developed for each of the canopy structure measures: 1) regression of the field data with the satellite imagery; 2 ) regression of the field data with the satellite imagery with kriging of the regression residuals; 3 ) regression of the field data with the satellite imagery with cokriging of the regression residuals with the satellite imagery; 4) kriging of the field data; and 5) cokriging of the field data with the satellite imagery. Only the results of the short term objective (increasing the number of field sample sites) will be discussed here.

\section{$\downarrow \quad$ STUdY AREA}

The research is being conducted in GTNP, a part of the Greater Yellowstone Area (GYA) which also includes Yellowstone National Park, seven National Forests (Bridger-Teton, Shoshone, Custer, Gallatin, Beaverhead, Targhee and Caribou), an elk refuge and two wildlife refuges. Major vegetation communities in the area include foothill grassland/shrub steppe, riparian, mountain shrub, low-elevation forest, middle-elevation forest, subalpine forest and alpine tundra. The low-elevation forest is dominated by Douglas fir (Pseudotsuga menziesii), the middle -elevation forests by lodgepole pine (Pinus contorta var. latifolia) and the subalpine forest by Engleman 
spruce (Picea engelmannii), subalpine fir (Abies lasiocarpa) and whitebark pine (Pinus albicaulis) (Marston and Anderson, 1991). In the middle-elevation forest, lodgepole pine is a persistent dominant and extends from the Absaroka Range in eastern Yellowstone National Park, across the Bridger-Teton National Forest to the south flank of the Teton Range (Clark, 1981).

\section{METHODS}

Preliminary field sampling was conducted during the summers of 1994, 1995, and 1996. Field sampling consisted of the systematic sampling of stand parameters within a $10 \times 10$ or $20 \times 25$ meter plot, depending on whether the trees were dense or sparse, respectively. All trees within the plot greater than $2.5 \mathrm{~m}$ in height were tallied in 5 centimeter diameter classes by species. Seedlings, those trees less than $2.5 \mathrm{~m}$ in height, were tallied in four height classes: $0.5-1.0 \mathrm{~m} ., \quad 1.0-1.5 \mathrm{~m}$., $1.5-2.0 \mathrm{~m}$., and $2.0-2.5 \mathrm{~m}$., by species. Increment cores were extracted from dominant trees that appeared to represent the pioneer cohort of each plot to estimate the year of stand origin. Average height of the overstory was calculated using a clinometer. Visual estimates of understory vegetation cover were recorded by species within twenty $0.5 \mathrm{~m} . \times 0.5 \mathrm{~m}$. quadrats established at equal intervals along four transects (five quadrats/transect). Ground cover not occupied by herbaceous or low woody plants was classified by percent cover into moss/lichen, litter, persistent litter, rock, or soil classes.

Following field work, basal area for living trees was computed using the mean diameter value for each size class (e.g., $2.5 \mathrm{~cm}$ for the $0.0 \mathrm{~cm}$ $5.0 \mathrm{~cm}$ size class) (Knight, 1978). Biomass for living overstory species was computed using the allometric equations from Gholz et al. (1979). Leaf area index (LAI) was computed for each stand using the basal area equations of Kaufman et al. (1982). These data will be used in concert with the Normalized Difference Vegetation Index (NDVI) derived from Landsat MSS imagery to drive the statistical and geostatistical modeling procedures.

\section{$\downarrow \quad$ RESULTS}

A total of eighteen sites were sampled during the 1997 field season, adding to the forty- two sites previously sampled, resulting in a total of sixty sites. Of the sixty sites, 53 are sapling sites (20 x 25m plot), and seven are seedling sites (10 x $10 \mathrm{~m}$ plots). Basal area had an average of 5.89 with a standard deviation of 2.72 for the seedling sites and an average of 31.82 with a standard deviation of 8.49 for the sapling sites. Biomass had an average of 1679.22 with a standard deviation of 697.80 for the seedling sites and an average of 6893.76 with a standard deviation of 1851.22 for the sapling sites. Leaf area index had an average of 1.03 with a standard deviation of 0.47 for the seedling sites and an average of 6.06 with a standard deviation of 1.70 for the sapling sites. NDVI exhibited a similar trend with an average of 181.90 with a standard deviation of 2.82 for the seedling sites and an average of 196.15 with a standard deviation of 4.54 for the sapling sites.

\section{CONCLUSION}

The field campaign of 1997 helped fill in the gaps among the sampling efforts from 1994 to 1996. A total of eighteen sites were sampled, raising the total sampled to date to sixty. This field sampling effort will support a modeling effort aimed at interpolating forest canopy structure information to areas within the park that will not be sampled. The resulting data sets will be useful to forest ecologists and planners as well as global change scientists.

\section{$\downarrow$ REFERENCES}

Clark, T.W. 1981. Ecology of Jackson Hole, Wyoming. Paragon Press. $110 \mathrm{p}$.

Gholz, H.L., Grier, C.C., Campbell, A.G., and Brown, A.T. 1979. Equations for Estimating Biomass and Leaf Area of Plants in the Pacific Northwest. Research Paper 41, Forest Research Laboratory, School of Forestry, Oregon State University, Corvallis, Oregon. 22 p.

Kaufman, M.R., Edminster, C.B., and Troendle, C.A. 1982. Leaf Area Determination for Subalpine Tree Species in the Central Rocky Mountains. Rocky Mountain Forest and Range Experiment Station Research Paper RM-238. U.S. Forest Service, Department of Agriculture. $7 \mathrm{p}$. 
Knight, D.H. 1978. Methods of Sampling Vegetation. Unpublished Manual, Department of Botany, University of Wyoming, Laramie, Wyoming. 67p.

Marston, R.A., and Anderson, J.E. 1991. Watersheds and Vegetation of the Greater Yellowstone Ecosystem. Conservation Biology, 5:338-346. 